OPEN ACCESS

Edited by:

Claudio Forte,

University of Turin, Italy

Reviewed by:

Antonio Boccardo,

University of Milan, Italy

Stefania Chessa,

University of Turin, Italy

*Correspondence:

Lisa Robbers

l.robbers@uu.nl

Specialty section:

This article was submitted to Animal Nutrition and Metabolism,

a section of the journal

Frontiers in Veterinary Science

Received: 16 February 2021

Accepted: 21 June 2021

Published: 19 July 2021

Citation:

Robbers L, Jorritsma R, Nielen M and Koets A (2021) A Scoping Review of

On-Farm Colostrum Management

Practices for Optimal Transfer of

Immunity in Dairy Calves.

Front. Vet. Sci. 8:668639

doi: 10.3389/fvets.2021.668639

\section{A Scoping Review of On-Farm Colostrum Management Practices for Optimal Transfer of Immunity in Dairy Calves}

\author{
Lisa Robbers ${ }^{1 *}$, Ruurd Jorritsma ${ }^{1}$, Mirjam Nielen ${ }^{1}$ and Ad Koets ${ }^{1,2}$ \\ ${ }^{1}$ Population Health Sciences, Faculty of Veterinary Medicine, Utrecht University, Utrecht, Netherlands, ${ }^{2}$ Wageningen \\ Bioveterinary Research, Lelystad, Netherlands
}

Newborn calves are agammaglobulinemic and rely for their first immune protection almost completely on the transfer of immune constituents via colostrum. Inadequate colostrum management practices such as on-farm colostrum storage practices and colostrum feeding methods could affect immune components in colostrum and subsequently immune status of the newborn calf. We conducted a scoping review to identify all literature on the interactions between several colostrum management factors and immunological colostrum quality and passive transfer of immunity. Three major stages were defined: milking methods, colostrum treatment and storage, and administration procedures. Separate CAB Abstracts searches were performed for each of the subjects of interest. The search process was completed on November 9, 2020. Colostrum should be milked as soon as possible, as IgG concentration diminishes over time, probably due to dilution. To minimize bacterial contamination, it is advised to pasteurize colostrum in small batches at maximal $60^{\circ} \mathrm{C}$ for 30 or 60 min. Freeze/thawing of colostrum does not or only slightly affect lgG concentrations, as long as thawing is done au bain-marie and temperature does not exceed $40^{\circ} \mathrm{C}$. In on-farm situations, it is difficult to determine the volume that should be fed as the variables contributing to the absorption of lgG by the newborn calf are many and include the quality of the colostrum, the bacterial contamination, the time interval between birth and first moment of feeding and the weight of the calf. Despite all knowledge regarding optimal colostrum management strategies, it remains challenging to predict the effects of certain colostrum management choices in field conditions. Therefore, we recommend measuring the colostral quality, weighing the newborn calf, adjusting the feeding volume accordingly to ensure optimal colostrum intake for each calf.

Keywords: colostrum management, calf feeding, immunity, colostrum storage, milking, scoping review 


\section{INTRODUCTION}

The first weeks of life are a critical period in the development of the newborn calf as it is very susceptible to various pathogens. Cows, just like other ruminants, have an epitheliochorial placenta which prevents the transfer of passive immunity to the neonate during gestation. Hence, newborn calves are agammaglobulinemic and rely for their first immune protection almost entirely on the transfer of immune constituents through the first ingested colostrum. Immunoglobulin (Ig) G is traditionally considered critical in assessing colostrum quality because it is the most abundant $\operatorname{Ig}$ (IgG accounts for $\sim 85-90 \%$ of the total Ig in colostrum) (1). Two major subtypes of IgG can be distinguished in colostrum: $\operatorname{IgG}_{1}$ which makes up $80-90 \%$ of the total IgG, and IgG . Besides IgG, also IgM (7\%) and IgA (5\%) are present in colostrum (1). Where IgG appears in monomeric form, $\operatorname{IgA}$ and IgM appear in multimeric form. The neonate absorbs all three immunoglobulin classes, but IgA is partly released back into the intestinal lumen to for local, mucosal protection (2). IgM is mainly involved in primary immune response. Because $\operatorname{IgA}$ and IgM have a relatively short half-life (3-4 days) compared to $\operatorname{IgG}(21-28$ days) $(3,4)$, they only perform protective functions in the neonate for a short time. Usually, colostrum quality is expressed in terms of IgG concentration, which is highly variable between cows $(5,6)$. Colostrum of high quality typically contains a concentration of $>50 \mathrm{~g} / \mathrm{L}$, while lower concentrations indicate colostrum of low quality (1). It has been widely accepted that a calf should have a serum IgG concentration of at least $10 \mathrm{mg} / \mathrm{mL}$ between 24 and $48 \mathrm{~h}$ after birth (1). By definition, there is a failed transfer of passive immunity (FPI) when this criterium is not met, which is correlated with higher incidence of early calf morbidity and mortality as reviewed extensively by many $(1,7,8)$. More recently, Lombard et al. suggested to revise this guideline into a new standard, in which the dose-dependent relationship between calf serum IgG concentration and calf morbidity is taken into account (9). In practice, achieving successful transfer of passive immunity through colostrum is one of the main challenges in calf rearing.

Optimal on-farm colostrum management is essential to ensure adequate transfer of passive immunity and provide the best start for newborn calves. Many studies have been conducted to define optimal management strategies for colostrum feeding. Farmers, veterinarians and feed advisors have adopted the "Three Q's" as a general guideline for providing colostrum: Quantity, Quality and Quickness of feeding. In addition, sometimes two "Q's" are added: "Quantifying the transfer of immunoglobulins" and "sQueaky clean" (10). In practice, farmers strive to provide a sufficient amount of high quality colostrum as quickly as possible to ensure adequate transfer of passive immunity. Meanwhile, bacterial contamination should be minimized and to ensure proper absorption by the calf, serum IgG concentrations should be monitored between 24 and $48 \mathrm{~h}$ of age. An overview of all existing knowledge on colostrum management and its effects on colostrum quality and immune transfer to the calf is lacking. We therefore conducted a scoping review on the effect of several onfarm management factors on immunological colostrum quality and transfer of passive immunity by the calf. We grouped the effects into (1) the milking methods, (2) colostrum treatment and storage and (3) administration procedures. The first two are aimed to optimize the quality of colostrum with regards to IgG concentration, while the latter aims to achieve most efficient colostral IgG uptake by the calf. Our research question for this scoping review was defined as: What is the up-to-date evidence on the interactions between on-farm colostrum management, colostrum quality and passive immunity.

\section{MATERIALS AND METHODS}

\section{Literature Search}

Separate CAB Abstracts searches were performed for each of the subjects of interest. All searches included the following terms: (cow OR cattle AND colostrum).mp. The "mp" includes all articles with selected key terms in their abstract, title, original title, broad terms, heading words, identifiers and cabicodes. To identify papers concerning milking methods, these general terms were combined with the term (milking).mp. To identify papers describing storage and treatment methods, the general terms were combined with the terms (storage OR treatment OR heating OR pasteurization OR pasteurization OR temperature OR refrigeration OR thawing OR heat OR frozen).mp. Finally, papers describing feeding methods were identified by extending the general terms to (cow OR cattle OR calves OR calf AND colostrum).mp, and combining these with (bucket feeding OR tube feeding OR esophageal feeding OR feeding method OR feeding technique OR feeding frequency OR bottle feeding OR suckling OR calf feeding).mp.

\section{Inclusion Criteria}

This review only includes peer-reviewed articles presenting primary research to farm-related management of fresh bovine colostrum for calf feeding and the effects on (colostral and/or serum) immunoglobulins, leukocytes and other potential immune components. Articles were written in English or Dutch, and articles were included only if full text was available. Articles published up until November 9, 2020 were included. Additional selection criteria were included for the separate topics. All selected papers contain studies with common breeds of dairy cattle that were healthy and did not undergo specific treatment before the study period (e.g., no specific vaccination prior to calving or dry feeding strategies). For the selection of papers on milking strategies, only papers addressing milking of dairy cows were included. For selecting papers describing storage and treatments, reports involving bacterial counts were included during the first selection phase. During the second evaluation (full text articles), studies on bacterial counts were only included if they contained information on immune parameters and did not involve in vitro studies on the effects of specific bacterial strains. For selecting the papers evaluating feeding methods, papers were included when colostrum feedings were from fresh bovine colostrum, when feedings occurred within $24 \mathrm{~h}$ after birth, and when serum immune concentrations were assessed at least within $24-48 \mathrm{~h}$ after birth. For suckling of the calf, beef cattle studies were selected as well. The first author performed data retrieval. For each search, titles and abstracts were scanned for the 
selection criteria described above. Of the remaining papers, the main text was evaluated for relevance. In addition, the first author assessed the articles when uncertainty existed on whether or not to include a paper; this was discussed with the second author.

\section{RESULTS}

\section{Milking Methods Search Methods}

There were 642 records identified using keywords for "milking methods" as described. Two hundred fifty-three records were excluded because they were not in English or Dutch. Title and abstract first screening led to the exclusion of 357 papers that did not contain original research data (such as reviews), were not peer reviewed (such as conference proceedings), and/or did not fit the inclusion criteria. The remaining 32 articles were assessed full text. Three reports were added based on references in full-text read articles. One paper was excluded for it was unavailable full text; six others were excluded because they did not fit the selection criteria. A flowchart summarizing the selection process can be found in Figure 1. In total, 28 articles were included, of which 2 animal studies and 26 population studies. An overview of the study types can be found in Table 1 .

\section{Time Between Calving and First Colostrum Milking}

Timing of first colostrum milking is thought to affect immunoglobulin concentrations of colostrum. Many studies agree that by shortening the interval between parturition and milking, the concentration of Ig in colostrum is higher, consequently improving colostrum quality $(6,11-20)$. Still, the time after which the immunoglobulin concentration starts to decline is debated. Conneely et al. found that colostral IgG concentrations in milkings occurring $0-3,3-6$, or $6-9 \mathrm{~h}$ postpartum were similar and reports a significant reduction over $9 \mathrm{~h}$ post-partum (13). These results are confirmed by other studies, that found no negative correlation between colostral IgG and time interval when milked within 3-9h post-partum (21-24). Kessler et al. (6) reported however that milking colostrum within $3 \mathrm{~h}$ post-partum results in significantly higher IgG concentration compared to milking colostrum later. Between 3 and $12 \mathrm{~h}$ postpartum the concentration remains relatively similar (6). Both Kruse and Moore et al. found highest colostral immunoglobulins in colostrum milked within $2 \mathrm{~h}(11,12)$. Morin et al. and Conneely et al. described, respectively, a 3.7 and $1.1 \%$ decrease in colostral IgG concentration with every hour the milking was delayed $(13,14)$, suggesting milking directly after calving is most optimal. A delay in first colostrum milking may result in dilution of the immunoglobulin content, as colostrogenesis and thereby the transfer of immunoglobulins into colostrum is believed to end at parturition. As the time interval until first milking increases, lactogenesis is initiated and milk yield increases (13). Several studies found a negative correlation between first milking yield and immunoglobulin concentration $(13,18,20,22,25,26)$, indicating that delayed milking leads to dilution of the colostrum, thus reducing the antibody concentration. However, Conneely et al. (13) argue that even after adjusting for the colostral weight, cows that were milked at a later time still produced colostrum with lower IgG concentration. Additionally, some studies did not find an association between increased first colostrum yield and the concentration of immunoglobulins $(12,23,24,27,28)$. Kessler et al. (24) propose that the process of colostrogenesis does not abruptly end at parturition and that immunoglobulin transfer continues a few hours after calving. This would explain their findings that colostrum milked within $30 \mathrm{~min}$ post-partum contains lower IgG concentrations than colostrum milked $3 \mathrm{~h}$ after calving (24).

\section{Fractional Milking Strategies}

Following parturition, colostrum can be milked out completely, but it is also possible to e.g., collect only the quantity needed to cover the needs of the calf and milk the cow partially. Using different fractions of colostrum (other than milking completely) may affect the colostral antibody concentrations. Stott et al. (29) studied whether colostrum collected from the cisterns contained higher concentrations of immunoglobulins. From each quarter, $100 \mathrm{ml}$ was collected, after which the remaining colostrum was milked completely. For IgG, IgM and IgA no concentration differences were observed between the cisternal and the complete colostrum (29). Other studies found similar results (30-32). However, Ontsouka et al. obtained samples on day 2 after calving, which usually contains lower levels of immunoglobulins (31). Godden and Hazel (33) assessed IgG concentrations in different fractions of colostrum. During the entire process of colostrum collection, every $30 \mathrm{~s}$ a $10 \mathrm{~mL}$ sample of colostrum was collected into a syringe through a sampling port that was located in the milk line. This enabled them to make a clear distinction of the separate fractions. In contrast to other findings, they describe a clear difference in IgG concentration between cisternal and composite samples. Moreover, they found higher IgG concentrations in cisternal colostrum compared to the first quartile, the first half and the first three quarters of the first milking. Milking 25, 50, and 75\% of colostrum showed no IgG concentration differences (33). Despite contradicting observations regarding fractional milking, the use of cisternal fractions of the first streaks of colostrum to estimate its quality is discouraged, as those samples may not represent total colostrum quality (33). Sroka et al. suggest milking completely and save the remaining colostrum after first feeding for the next feedings, since consecutive milkings from cows milked out completely contain lower IgG concentrations (34).

The effect of milking individual quarters at different time points as fractional milking strategy is not extensively studied. Madsen et al. (35) reported some small differences in IgG concentrations when one quarter was omitted for milking, but omitting one quarter did not affect total IgG yield. This was explained by the neutralization of all quarters in the fourth milking (35). Also Gomes et al. and Kessler et al. did not find any significant differences in IgG, IgM or IgA concentration between quarters $(24,36)$, although large variations in production between quarters were observed (24). Baumrucker et al. on the other hand found that the front quarters produced colostrum with a higher concentration of IgG compared to the rear quarters (37). 


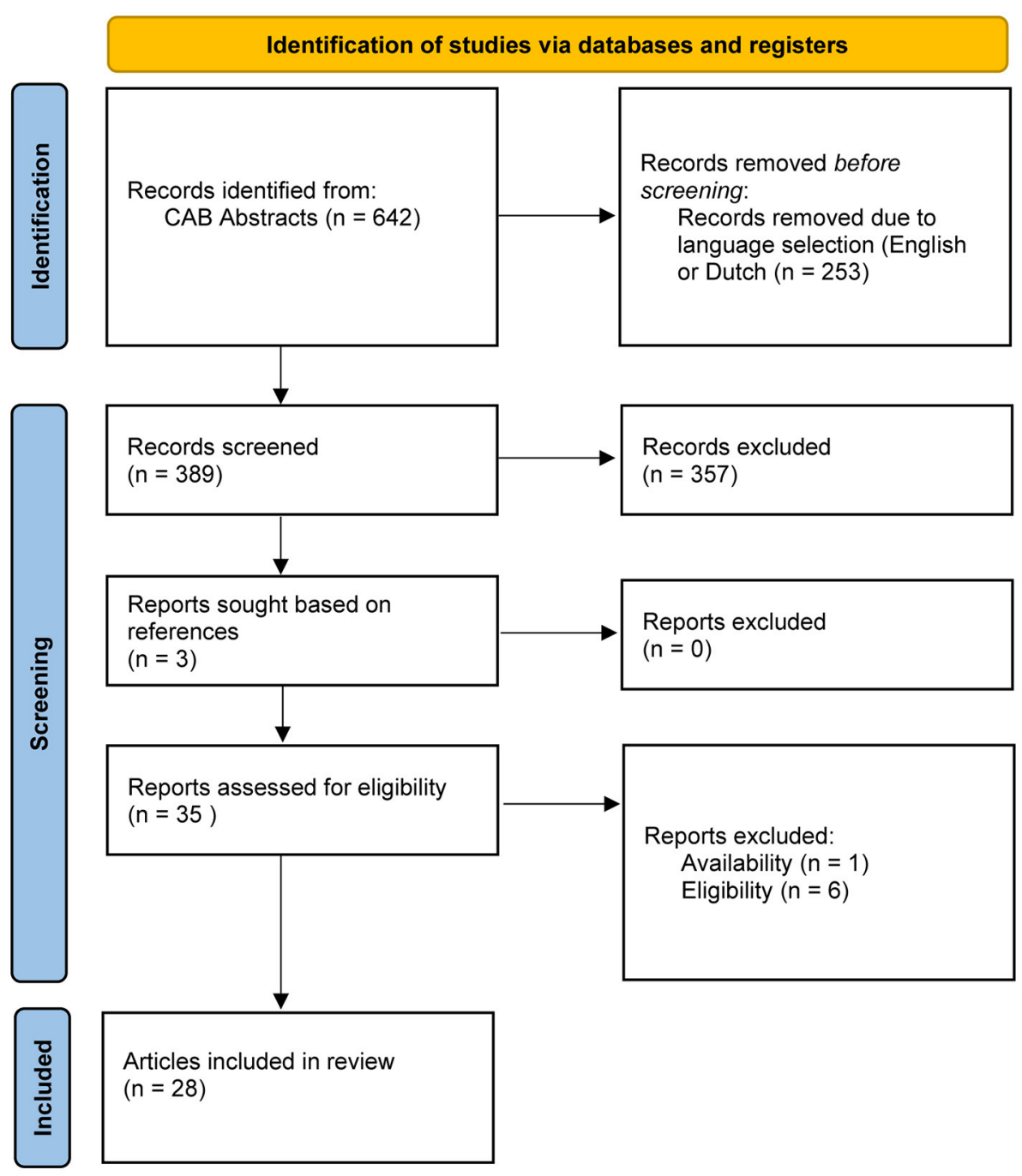

FIGURE 1 | Flowchart depicting the article selection process for the subsection "milking methods."

TABLE 1 | Overview of the study types included in the results, separate columns for each of the sections: colostrum milking, treatments and storage, and administration procedures.

\section{Milking methods}

Animal studies

Laboratory studies

Population studies

Total

2

26

28
Colostrum treatments and storage

24
26
6
56

56
Administration procedures

36

18

54
Total

62

26

50

138

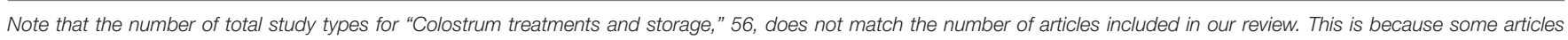
present more than one study type, e.g., a combination of laboratory study type and animal study type.

\section{Colostrum Treatment and Storage}

\section{Search Methods}

There were 1595 records identified using keywords for "milking methods" as described. Four hundred twenty-five records were excluded because they were not in English or Dutch. Title and abstract first screening led to the exclusion of 1101 papers that did not contain original research data (such as reviews), were not peer reviewed (such as conference proceedings), and/or did not fit the inclusion criteria. The remaining 69 articles were assessed full text. Four reports were added based on references in full-text read articles. Three papers were excluded for they were unavailable full text; twenty-one others were excluded because 
they did not fit the selection criteria. A flowchart summarizing the selection process can be found in Figure 2. In total, 49 articles were included, of which 24 animal studies, 26 laboratory studies and six population studies. An overview of the study types can be found in Table 1. The numbers in Table 1 for "Colostrum treatment and storage" add up to 56 instead of 49 . This is because seven articles combined two study types, for example laboratory study and animal study.

To review the effects of storage, we decided to make a distinction between short term and long term storage or treatment effects. We defined short term storage or treatment as on-farm practices applied to freshly milked colostrum used to feed calves within $48 \mathrm{~h}$ after milking. In case dams cannot produce a sufficient volume or high colostrum quality, there is a need for stored colostrum from other cows that calved earlier. Thus, it is important to evaluate the effect of long term storage of colostrum on quality as well. We defined long term storage a method applied to store or treat fresh colostrum for a period longer than $48 \mathrm{~h}$ after milking.

\section{Short Term Storage}

Some studies have investigated the effect of short term storing conditions on the presence of (pathogenic) microorganisms in colostrum. Fewer studies looked into effects on immunological parameters.

\section{Storing at Different Temperatures}

Storing colostrum at room temperature or at $4{ }^{\circ} \mathrm{C}$ did not affect IgG concentration (38). However, an association was found between increased bacterial counts $(>1,000,000)$ and decreased calf serum IgG levels after storage at higher temperature $\left(22^{\circ} \mathrm{C}\right)$ (39). With respect to storing colostrum in a refrigerator, Langel et al. note that refrigeration $\left(4^{\circ} \mathrm{C}\right)$ up to $8 \mathrm{~h}$ did not affect cell viability (40), whereas effects of refrigeration for a longer period are yet unclear. We did not find other literature investigating effects of short term storage of colostrum such as temperature and/or duration, on colostral Igs or other immune components in colostrum.

\section{Pasteurizing Colostrum}

Pasteurization of milk is widely used to eliminate the number of microorganisms to a minimum at which milk can safely be used for human consumption. Pasteurization can also be applied to minimize the amount of pathogens in colostrum in order to minimize health risks for the calf. As the effects of pasteurization on pathogen elimination are widely ascertained, we focus on the effects of pasteurization on the immunological content of colostrum by looking at immunoglobulins in particular. In addition, we payed attention to the apparent efficiency of absorption (AEA) of immunoglobulins by the neonate.

Effects on Colostrum IgG. Protein structure can be altered by temperature and therefore heating of colostrum can influence availability and functionality of proteins including immunoglobulins. The majority of studies investigating pasteurization effects focus on colostral or calf serum IgG. In all existing literature a variety of combinations regarding temperature and duration of pasteurization is applied and therefore these studies are a challenge to compare. We summarized the results of the existing literature in Supplementary Table 1. The majority of studies show that colostral IgG concentration is not (41-53) or only slightly affected (54-57) by heating at $<60^{\circ} \mathrm{C}$ for either 30 or $60 \mathrm{~min}$. In contrast, heating of colostrum above $60^{\circ} \mathrm{C}$ frequently resulted in significant loss of colostral IgG $(41-48,50,54,58-60)$. Heating colostrum at a temperature of $60^{\circ} \mathrm{C}$ for 30 or 60 min leads to significant reduction in bacterial counts, while viscosity remains similar and there is only a slight reduction in colostral IgG concentration (54). Several studies noted that the loss of IgG depended on the original quality of colostrum and found that colostrum of high quality suffered from a greater reduction in IgG concentration compared to colostrum of low quality $(41,47,58)$. Meylan et al. argue that high quality colostrum is more likely to aggregate, leading to protein clump formation, which results in denaturation of the protein (58). However, different results were obtained by Balthazar et al., who observed a greater IgG losses for low-quality colostrum compared to high-quality colostrum (61).

Effects on Serum IgG and Apparent Efficiency of Absorption. While pasteurization of colostrum can result in slight reduction of colostral IgG concentration, it has been suggested that calf serum IgG levels are potentially increased when colostrum is pasteurized. The study by Johnson et al. (42) was one of the first to describe that there was no noteworthy difference in IgG observed between pasteurized and unpasteurized colostrum, but calf serum IgG levels were significantly higher in calves fed pasteurized colostrum (22.34 vs. $18.07 \mathrm{mg} / \mathrm{mL}$ ) (42). Subsequent studies revealed similar results: heat treatment of colostrum at $60^{\circ} \mathrm{C}$ for 30 or $60 \mathrm{~min}$ preserved both viscosity and IgG levels of colostrum, while serum IgG and AEA was higher in calves fed the heat treated colostrum compared to calves fed unheated colostrum (43, 44, 47-49, 57, 62, 63). Possibly, degradation and denaturation of proteins that would otherwise compete with the intestinal absorption of $\operatorname{IgG}$ contributes to increased IgG absorption after pasteurization. Also, immunoglobulins transferred with colostrum could bind to bacteria, thereby inhibiting them from passing the epithelial barrier. When the number of bacteria is reduced by pasteurization, this can lead to increased amounts of free immunoglobulins which can pass the epithelial barrier. This theory is supported by the work of Gelsinger (62). Colostrum with a high bacterial count-but with similar IgG concentration-resulted in decreased AEA compared to colostrum low in bacterial count (62). However, in an earlier study performed by Elizondo-Salazar no such difference in AEA was noted (44). Perhaps entire bacterial dead cells or their fragments may still attach to colostral immunoglobulins in the gut and thus reduce their absorption.

Although pasteurization of colostrum above $60^{\circ} \mathrm{C}$ is generally associated with decreased colostral immunoglobulins, several studies noted that this does not automatically lead to decreased calf serum concentrations. Tyler et al. (64) studied the effects of pasteurizing at different temperatures and found that heating colostrum to $63^{\circ} \mathrm{C}$ for $30 \mathrm{~min}$ did not affect serum IgG in calves compared to unpasteurized colostrum. Pasteurization at 


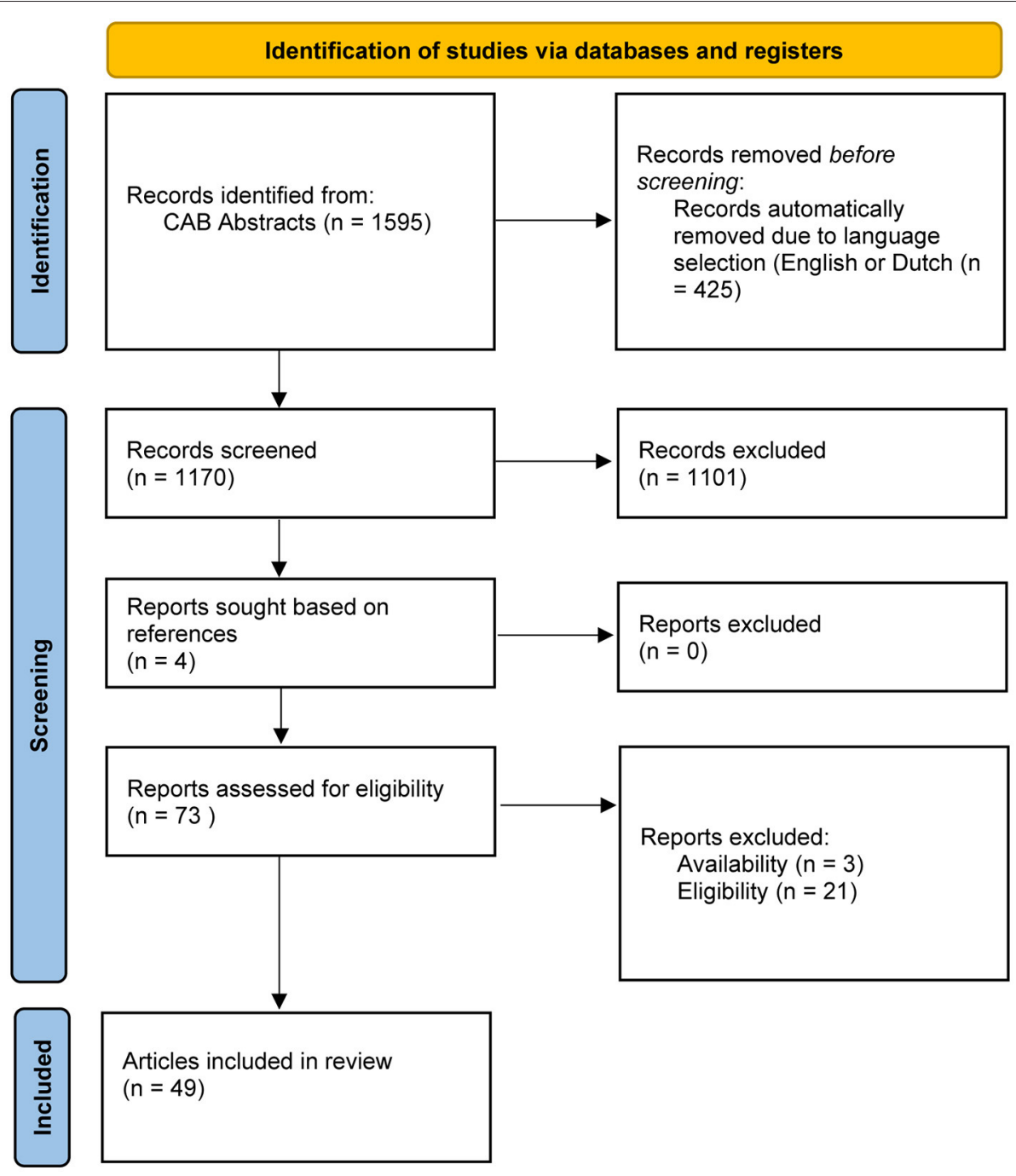

FIGURE 2 | Flowchart depicting the article selection process for the subsection "colostrum treatment and storage."

$76^{\circ} \mathrm{C}$ did lead to lower serum IgG levels (64). Also, Bush et al. (65) even found calf serum IgG to be increased $12 \mathrm{~h}$ after calves ingested pasteurized colostrum $\left(63^{\circ} \mathrm{C}\right)$ compared to calves fed unpasteurized colostrum. In subsequent measurements, this difference diminished (65). Also Lakritz et al. found no significant effect on serum IgG concentrations between calves fed pasteurized $\left(76^{\circ} \mathrm{C}\right)$ or unpasteurized colostrum (66). However this study was performed with a small sample size and results should be interpreted with care. Stabel reported that over the long term (1 month) no differences in calf serum IgG are found between calves fed pasteurized colostrum $\left(65^{\circ} \mathrm{C}\right)$ and calves that suckled fresh unpasteurized colostrum (67).

While the majority of the studies focus on loss of colostral IgG concentration, few paid attention to loss of IgG functionality. McMartin et al. performed serum neutralization assay to determine colostral antibody activity in samples pasteurized at either 60 or $63^{\circ} \mathrm{C}$. While no adverse effects of pasteurization on antibody activity were found, the authors emphasize that these results should be interpreted with care, as many samples were lost due to congealing in the process of pasteurization (41).

Effects on Other Immunological Factors. Lactoferrin is an immune component of colostrum, which is known to possess immunomodulatory and antimicrobial properties and is therefore interesting to look into. A few studies have looked into the effects of heating colostrum on lactoferrin levels. Pasteurization at $60,63,72$, and $76^{\circ} \mathrm{C}$ lead to significant reduction of lactoferrin concentrations in colostrum and in calf serum, as visualized in Supplementary Table $2(66,68,69)$. These results largely agree with the study by Shimo et al., who recorded significant aggregation and denaturation of lactoferrin at temperatures above $63^{\circ} \mathrm{C}$, especially when $\mathrm{pH}$ was increased as well. Below $63^{\circ} \mathrm{C}$, no significant denaturation occurred (70). Other immunological compounds in colostrum such as 
cytokines were studied as well. Gelsinger and Heinrichs (55) found that neonatal absorption of colostral interferon- $\gamma$ was not affected by pasteurization at $60^{\circ} \mathrm{C}$ for $60 \mathrm{~min}$. On the other hand, interleukin $1 \beta$ concentration in calves receiving heat-treated colostrum was decreased. The authors suggest that the neonatal immune response is not inhibited by heat treatment of colostrum (55). In the same study, calves were subcutaneously challenged with ovalbumin to determine B cell activity and thus antibody production. Calves receiving heat treated colostrum showed higher ovalbumin specific IgG levels to this challenge indicating that neonatal B-cell function was not affected by heat treatment of colostrum. However, calves receiving unheated colostrum tended to recover their average daily gain faster after the immune challenge. During the Minnesota Dairy Health Conference in 2012 Godden et al. discussed their study investigating whether viability of colostral immune cells was affected by the process of pasteurization. Indeed, viability was reduced but not completely eliminated after pasteurizing for $60 \mathrm{~min}$ at $60^{\circ} \mathrm{C}$. Also the authors state that although viability of colostral immune cells is reduced, more research is required regarding functionality and biological meaning of colostral cells (45).

\section{Long Term Storage and Treatments Freezing and Thawing of Colostrum}

As freezing will always be inextricably associated with thawing, investigating the effect of freezing on colostrum quality should be combined with thawing, just as thawing should be studied in combination with freezing. Hence, we will review studies investigating freezing and/or thawing and combine results in our analysis.

Effects on Colostrum IgG. Several studies examined the effects of freeze/thawing on IgG content of colostrum and serum IgG (Supplementary Table 3). To our best knowledge, there are no studies investigating thawing at room temperature.

Wiking and Pedersen (71) studied several ways to thaw and heat colostrum in a microwave oven. Heating of refrigerated colostrum samples did not directly lead to a loss of IgG. Thawing of frozen colostrum by microwave resulted in unevenly heated colostrum and clotting, however no information of IgG concentration was reported (71). Jones et al. (72) examined thawing by microwaving at two different microwave settings (325 and $650 \mathrm{Watt}$ ) and found no differences in IgG or IgM content as compared to thawing au bain-marie $\left(45^{\circ} \mathrm{C}\right)$. However, small losses of IgA were found (72). Balthazar et al. found that increasing the power of a microwave was associated with a significant greater loss of $\operatorname{IgG}_{1}: 20 \%$ loss at $200 \mathrm{~W}$ vs. $31 \%$ loss at $350 \mathrm{~W}(61)$. Heating to 50 and $60^{\circ} \mathrm{C}$ au bain-marie resulted in a similar IgG loss as heating at $40^{\circ} \mathrm{C}(8 \%)$, while heating above $60^{\circ} \mathrm{C}$ resulted in a significant $(26 \%)$ reduction in $\operatorname{IgG} 1$. This is in line with other studies on pasteurization showing greater loss of IgG when colostrum is heated above $60^{\circ} \mathrm{C}$. Losses of $\operatorname{IgG}_{1}$ were greater for the low quality and thus low $\operatorname{IgG}_{1}$ fresh samples compared to the high quality fresh samples (61). With regard to repeated freeze/thawing, Haines et al. did not find significant changes in IgA, IgM or IgG concentrations in a single colostrum sample after multiple freeze-thawing cycles with a water bath at $37^{\circ} \mathrm{C}(73)$. However, since this study only included one sample these results should be interpreted with care. A larger study by Morrill et al. (74) showed that freeze/thawing for a single time does not reduce colostral IgG concentration. Compared to fresh colostrum, repeated freeze/thawing leads to a significant decrease of 7.8 and $7.7 \%$ for two and three freeze/thaw cycles, respectively (74). To our knowledge, no studies have examined how repeated freeze/thawing affects colostral immunoglobulin stability or function.

Effects on Serum IgG. Few studies looked into the effects of feeding colostrum after freezing/thawing on serum immunoglobulin concentration of neonate calves. Olson (75) found that both serum $\operatorname{IgG}_{1}$ and $\mathrm{IgG}_{2}$ levels were lower in calves fed au bain-marie heated $\left(41^{\circ} \mathrm{C}\right)$ colostrum compared to calves fed microwave heated colostrum $\left(312 \mathrm{~W}\right.$, heated to $\left.41^{\circ} \mathrm{C}\right)$, while colostral $\operatorname{IgG}_{1}, \operatorname{IgA}$ and $\operatorname{IgM}$ concentrations were similar and the $\mathrm{IgG}_{2}$ was only marginally lower. The authors note that these results should be interpreted with care, since the size of the study was quite small (75). Holloway et al. and Donovan et al. found no significant differences in serum IgG concentration between calves fed frozen and thawed colostrum and calves fed fresh colostrum $(76,77)$.

Effects on Other Immunological Factors. With respect to other immune components of colostrum, Holloway et al. (78) studied whether freeze/thawing affected lactoferrin concentrations in colostrum and calf serum. No difference in lactoferrin concentrations was observed between fresh and frozen colostrum. Serum lactoferrin concentration on day 2 did not differ between the calves fed fresh or freeze/thawed colostrum, however on days 4 and 7 serum concentrations were higher in the freeze/thawed colostrum fed calves. Unfortunately, the authors were unable to determine whether the measured serum lactoferrin was derived from colostrum or from endogenous origin (78). In addition to immunoglobulins and lactoferrin, colostrum contains maternal leukocytes as well. The general opinion is that leukocytes remain viable and functional under certain specific circumstances: the optimal temperature for mammalian cells is $37^{\circ} \mathrm{C}$, increasing the temperature above $42^{\circ} \mathrm{C}$ leads to denaturation of proteins and destruction of the cell, and freezing leads to intracellular ice crystal formation and thereby to damage and even lysis of cells. The assumption that colostral cells are indeed destroyed during freezing is supported by the studies by Novo et al. $(79,80)$. Using Trypan blue to check for cell viability, they report that no viable cells were found in their freeze/thawed colostrum $(79,80)$. Many papers studying the effects of leukocytes in colostrum make use of freeze/thawing for their control group of cell-free colostrum. Donovan et al. (77) studied the functionality of maternal colostral cells in neonatal calves. Calves were fed fresh colostrum, freeze/thawed colostrum or cell-free colostrum, all from dams vaccinated against Bovine Viral Diarrhea Virus (BVDV). The group fed fresh colostrum, with colostral cells, showed increased in vitro proliferative responses after stimulation with BVDV. Both the thawed and cell-free colostrum groups did not. The observed difference was attributed to the functionality of transferred maternal 
cells (77). These results combined with other results of studies using freeze/thawing as a valid method to lyse maternal cells in colostrum, indicate that freezing of colostrum indeed destructs colostral leukocytes $(40,79-81)$. On the contrary, Stieler et al. (82) found increased neutrophilic activity in calves fed fresh frozen colostrum compared to calves fed fresh colostrum, although not significant. No differences in activation capacity was observed after follow up with milk replacer for 21 days. The authors attributed the increased neutrophilic activity in the frozen/thawed colostrum fed calves to the release of transfer factors by lymphocytes in response to freezing, leading to stimulation of the cellular immune response (82).

\section{Other Treatments}

Few studies have experimented with high pressure techniques to eliminate bacterial counts in colostrum. Masuda et al. (83) reported effective suppression of bacterial growth for 9 days at $4^{\circ} \mathrm{C}$ after treating colostrum at 300 and $400 \mathrm{MPa}$ for $10 \mathrm{~min}$. Up to $300 \mathrm{MPa}$, IgG remained intact, but application of $400 \mathrm{MPa}$ resulted in altered viscosity of the colostrum and denaturation of $\operatorname{IgG}$ (83). Indyk et al. (84) and Foster et al. (85) found colostral IgG to be stable up to $400 \mathrm{MPa}$ treatment, as long as duration was limited to $30 \mathrm{~min}$. Increasing pressure (500 or $600 \mathrm{MPa}$ ) or duration resulted in increased denaturation and aggregation (85). Apparently, IgG in colostrum is more stable compared to IgG isolated from colostrum. Probably the colostral environment enhances the stability of immunoglobulins (84). The use of formaldehyde to preserve colostrum is sometimes applied in warm ambient climates when refrigeration is not an option. Mbuthia et al. found treatment with formaldehyde to be the best method for preserving immunoglobulin content in colostrum for up to 4 weeks compared to treatment with formic acid or natural fermentation (86).

\section{Administration Procedures Search Methods}

There were 1407 records identified using keywords for "milking methods" as described. Four hundred eighty-four records were excluded because they were not in English or Dutch. Title and abstract first screening led to the exclusion of 923 papers that did not contain original research data (such as reviews), were not peer reviewed (such as conference proceedings), and/or did not fit the inclusion criteria. The remaining 59 articles were assessed full text. Seven reports were added based on references in full-text read articles. Seven papers were excluded for they were unavailable full text; five others were excluded because they did not fit the selection criteria. A flowchart summarizing the selection process can be found in Figure 3. In total, 54 articles were included, of which 36 animal studies and 18 population studies. An overview of the study types can be found in Table 1.

Achieving adequate passive immunity depends on timely ingestion of a certain level of immunoglobulins and the absorption ability of the calf. In this paragraph we discuss studies looking into the effect of time interval between birth and first feeding, volume of first feeding, and equipment used for colostrum feeding on calf serum Ig status.

\section{Timing of First and Subsequent Feedings}

While some studies failed to find an association between timing of first feeding and serum IgG concentration $(87,88)$, the study by Keulen et al. showed that besides volume and quality of first colostrum, also the timing of first feeding partially explains variation in calf serum IgG (89). Indeed, most studies agree that the ability to absorb IgG declines with delaying first colostrum feeding. Still, much uncertainty exists about the exact time period to which the first feeding can safely be delayed without affecting the ability to absorb IgG. An early study by Smith et al. noted that calves receiving their first colostrum at $10-12 \mathrm{~h}$ after birth, showed a larger proportion of low serum immunoglobulin cases compared to calves receiving their first colostrum feeding within $8 \mathrm{~h}$. The study did not look further into the association between timing of first colostrum feeding and serum IgG or absorption rate (90). While some studies find it safe to feed the first colostrum up until $8 \mathrm{~h}$ of age without affecting IgG absorption (91), some claim the absorption rate starts to decline earlier, around $6 \mathrm{~h}$ of age (92) or even after $4 \mathrm{~h}$ (93-95). These last studies are in line with the study by Chigerwe et al., where no effect of time $(<4 \mathrm{~h})$ on FPT was observed (96). Another study by Chigerwe et al. recommended feeding of colostrum within $2 \mathrm{~h}$ of birth (97). The study by Osaka et al. shows a gradual decline in AEA over time for the first $12 \mathrm{~h}$. After $12 \mathrm{~h}$, a more rapid decline is observed (98). Some studies used models to estimate effects of delayed colostrum intake on calf serum IgG. One model showed that calf serum IgG concentration decreased with $2 \mathrm{mg} / \mathrm{ml}$ with every $30 \mathrm{~min}$ delay in colostrum intake (99), another found a decrease of with $0.32 \mathrm{mg} / \mathrm{ml}$ with each hour the colostrum ingestion is delayed (63). With respect to other immune components, Zanker et al. showed that delayed feeding of colostrum up to $24 \mathrm{~h}$ post-partum does not affect hematological values such as the total number of leukocytes in the neonate (100).

Absorption of IgG can be affected by the timing of the first colostrum, but also by timing of subsequent feedings. In the study by Fallon et al. it was shown that an additional feeding within $12 \mathrm{~h}$ significantly increased the serum immunoglobulin content (101). Timing of first colostrum feeding also affects the effectiveness of subsequent colostrum feedings. Calves fed colostrum within the hour with subsequent feedings at intervals of $8 \mathrm{~h}$ showed higher serum IgG than calves fed their first colostrum at 16 or $24 \mathrm{~h}$ followed by the same subsequent feedings (91).

\section{Volume of Feeding}

Many studies have attempted to determine the volume that should be consumed by the newborn calf to obtain first passive immunity. While investigations were carried out carefully, they differ from each other in terms of colostrum quality and timing of the first feeding. Therefore, a quantitative comparison of these studies is hardly possible. Some studies suggest to determine colostrum volume by means of the bodyweight of the newborn calf $(102,103)$. Conneely et al. propose that calves should ingest a volume corresponding to $8.5 \%$ of their body weight (within $2 \mathrm{~h}$ of age) (102). Some studies however claim that calves need to ingest a fixed amount of IgG to achieve successful transfer of passive immunity (serum IgG concentration $>10 \mathrm{mg} / \mathrm{ml}$ ) within $24-48 \mathrm{~h}$ 


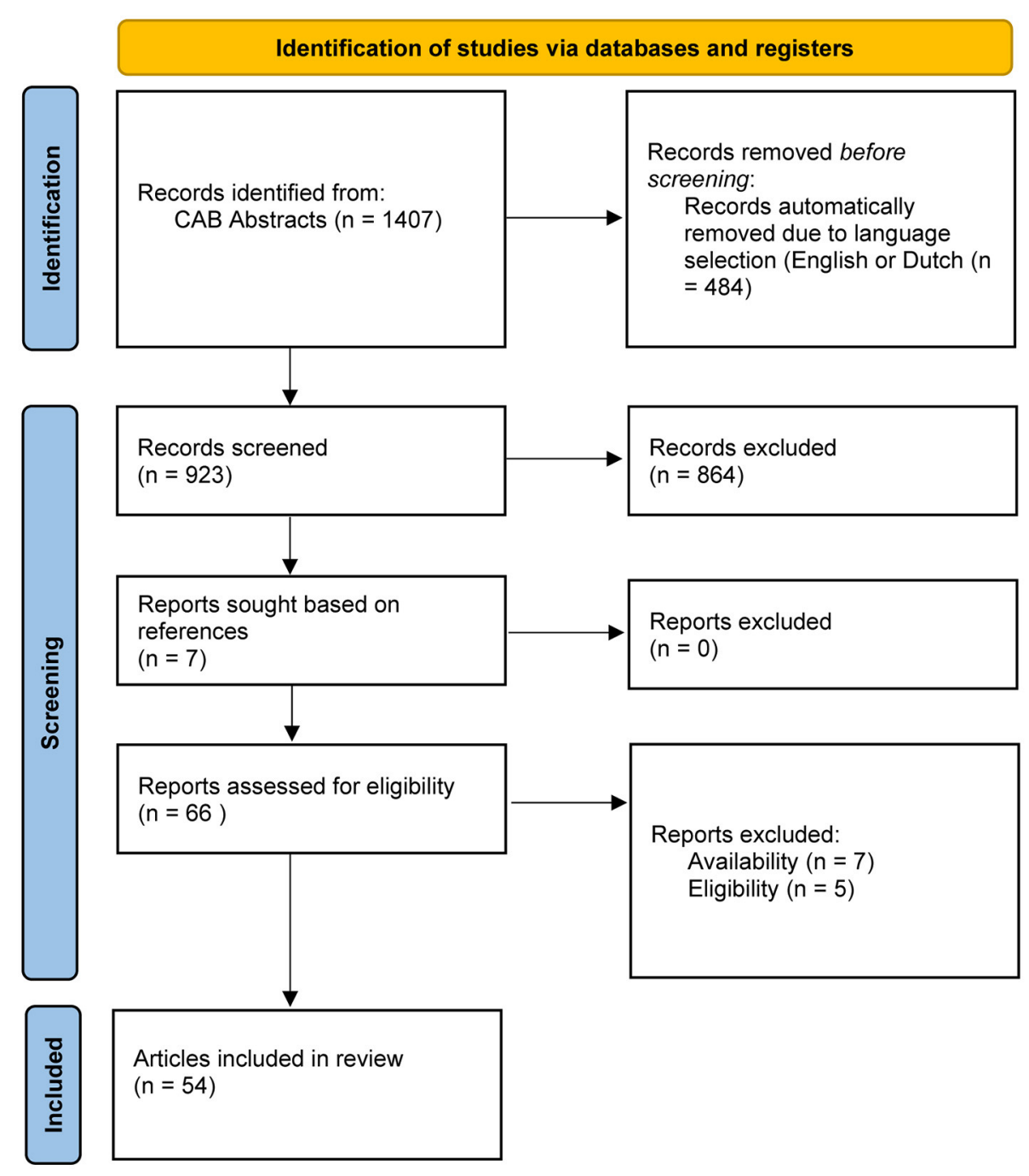

FIGURE 3 | Flowchart depicting the article selection process for the subsection "administration procedures."

of age. Some propose to provide at least 100 grams of IgG in total $(26,104)$, others deem this insufficient and suggest to feed 150200 gram of IgG or possibly even more $(97,105)$. Morin et al. (105) conducted a series of experiments in which they extensively studied several combinations of colostral quality, volume and timing of feeding on serum IgG in newborn calves. They found that feeding $4 \mathrm{~L}$ of high quality colostrum $(60.1 \mathrm{mg} / \mathrm{ml})$ within $3 \mathrm{~h}$ after birth, followed by another $2 \mathrm{~L}$ at $12 \mathrm{~h}$ after birth resulted in highest serum IgG at both $24(31.1 \mathrm{mg} / \mathrm{ml})$ and $48 \mathrm{~h}$ after birth $(30.4 \mathrm{mg} / \mathrm{ml})$. In total, these calves consumed $>360 \mathrm{~g}$ IgG. Calves receiving 240 grams of IgG, divided over 2 feedings of $2 \mathrm{~L}$ showed serum IgG concentrations of $>20 \mathrm{mg} / \mathrm{ml}$ at both 24 and $48 \mathrm{~h}$ after birth (105), indicating sufficient transfer of passive immunity. For low quality colostrum $(32.9 \mathrm{mg} / \mathrm{ml})$, they recommend to feed an additional $2 \mathrm{~L}$ at $6 \mathrm{~h}$ of age next to feeding $2 \mathrm{~L}$ at birth and $12 \mathrm{~h}$ of age (105). Different conclusions were drawn by Jaster (106). For low quality colostrum he observed higher serum IgG levels in calves fed $4 \mathrm{~L}$ at once compared to calves receiving the same amount equally divided over a feeding moment at birth and at $12 \mathrm{~h}$. For calves fed high quality colostrum, higher serum IgG levels were observed at 24 and $48 \mathrm{~h}$ when they were fed $2 \mathrm{~L}$ at birth followed by another $2 \mathrm{~L}$ at $12 \mathrm{~h}$ compared to calves fed $4 \mathrm{~L}$ at once, suggesting a maximal absorption capacity for IgG (106). Kaske et al. found also that providing $4 \mathrm{~L}$ containing 213 grams of IgG resulted in highest serum IgG levels $(25.2 \mathrm{mg} / \mathrm{ml})$. Feeding $2 \mathrm{~L}$ containing 97.4 grams of IgG resulted nevertheless in serum concentrations of $14.1 \mathrm{mg} / \mathrm{ml}$, which is still above the threshold of $10 \mathrm{mg} / \mathrm{ml}$ (107). Hopkins and Quigley point out that providing $3.8 \mathrm{~L}$ in either one or two feedings results in equal serum IgG concentrations, considered colostrum is of good quality (>50 g/L IgG) (108). Chigerwe et al. (96) suggest calves should voluntary ingest as much colostrum as possible within $4 \mathrm{~h}$ of birth. Depending on the volume that is voluntarily ingested, they recommend a second feeding at $12 \mathrm{~h}$ of age (96). An onfarm study by Halleran et al. found calves fed $5.6 \mathrm{~L}$ within $12 \mathrm{~h}$ of age had significant higher serum IgG concentrations than calves 
fed 4L (109). A large retrospective study identifying risk factors contributing to FPT by Renaud et al. showed that feeding $>6 \mathrm{~L}$ within the first $24 \mathrm{~h}$ of life was associated with decreased risk of FPT (110).

\section{Feeding Methods}

Many studies evaluated the effectiveness of several feeding methods to achieve successful transfer of passive immunity. Many studies looking into suckling with the dam showed that voluntary suckling $(111,112)$ and assisted suckling (113-115) can result in sufficient serum immunoglobulin concentrations. However, most studies report that suckling with the dam leads to high risks of FPI $(26,101,116-120)$. A possible explanation is that there seems to be a large variation in the time it takes calves to voluntarily suckle (121) and this can increase up to more than $6 \mathrm{~h}$ (122). Studies by McBeath and Logan and Rajala and Castren therefore point out the importance of supervision when calves are left with the dam to suckle $(99,123)$. Additional studies showed that calves assisted to suckle after $6 \mathrm{~h}$ were still able to achieve proper transfer of IgG, while those not assisted showed FPI $(95,122,124)$. Altogether, it appears that (assisted suckling) can lead to adequate transfer of passive immunity, but these methods do in general result in lower serum IgG levels when compared to active methods to deliver colostrum, such as esophageal or bottle feeding.

The use of a nipple bottle or (nipple) bucket is a common method for on-farm administration of colostrum. With respect to feeding with a nipple bottle, voluntary intake of colostrum by nipple bottle leads in many cases $(31 \%)$ to insufficient $(<2 \mathrm{~L})$ ingestion of colostrum (125). While some studies reported higher immunoglobulin concentrations in calves that were nursed by the dam in comparison with calves fed by nipple bottle (112, $114)$, others found no difference $(115,126)$ or higher serum immunoglobulin concentrations for bottle fed calves $(113,127)$. When comparing feeding colostrum with a nipple bottle or bucket, no significant difference in serum IgG was observed at 24 or $48 \mathrm{~h}(128)$ or at $96 \mathrm{~h}(101)$. The use of an esophageal feeder is effective for achieving adequate passive immune transfer (129, 130). Several studies have compared the use of esophageal feeding of colostrum to other feeding methods (Supplementary Table 4). When compared to voluntary suckling, esophageal feeding seems to be the better option for preventing FPI (26). However, some studies in beef calves suggest that when calves are assisted for suckling, serum IgG levels are comparable to that of calves fed with esophageal feeder $(131,132)$. When bottle and esophageal feeding methods are compared, esophageal feeding results in either higher (107) or comparable serum IgG concentrations (133-138). Kaske et al. showed increased serum IgG levels in calves fed $4 \mathrm{~L}$ colostrum by esophageal tube compared to $2 \mathrm{~L}$ bottle fed calves (107), however these feedings differ both in volume and in method offered and therefore these results are difficult to compare. A more comprehensive study was carried out by Godden et al. (104) by investigating the differences between esophageal and bottle feeding at two different volumes. When using a fixed volume of $3 \mathrm{~L}$ colostrum replacer by either bottle or esophageal feeding, no differences in serum IgG were observed, which was later confirmed by Desjardins-Morrissette et al. as well $(104,136)$. However, feeding a smaller volume of $1.5 \mathrm{~L}$ resulted in higher serum IgG levels in bottle fed calves when compared to tube fed calves. This result implies a possible association between the method of feeding, the volume fed and the serum IgG in calves. As pointed out by Lateur-Rowet and Breukink (130) feeding colostrum with the use of an esophageal feeder led to failure of the esophageal groove reflex, consequently leading to colostrum being led to the rumen and reticulum, instead of the abomasum. Rapid flow from reticulorumen to abomasum was observed though (130). Kaske et al. estimated that the time of emptying the contents of the reticulum into the abomasum lies between 2 and $3 \mathrm{~h}$ (107). This may explain the results found by Godden et al. (104): when smaller volumes of colostrum are fed by drenching, the reticulum would not easily overflow and colostrum does not enter the abomasum quickly. However, when larger amounts are fed, the reticulum overflows and colostrum is directly transferred to the abomasum where first digestion occurs (138). Chigerwe et al. (97) calculated the optimal volume fed by esophageal tube for adequate transfer of passive immunity. Calves fed by esophageal tube require at least 150-200 grams colostral IgG, which can be translated to the recommendation of $3 \mathrm{~L}$ colostrum as soon as possible after birth, given the colostral Ig concentration is at least $50 \mathrm{mg} / \mathrm{ml}$ (97).

\section{DISCUSSION}

We attempted to provide a complete overview of all existing literature about on-farm colostrum management strategies and their effects on colostrum quality and calf immune status. With respect to milking methods, most studies included are observational population studies ( 26 out of 28 ). Results obtained from this type of study designs are often a valid reflection of field conditions and therefore have high external validity. The majority of the studies agrees that increasing the interval between calving and first milking decreases the concentration of IgG in colostrum. Probably, this reduction in IgG concentration is largely, but maybe not only, the result of a dilution effect. Dilution also explains decreased IgG concentrations in subsequent milkings. Therefore, milking the cow completely and as soon as possible after parturition is highly encouraged and will likely result in the highest colostral IgG concentrations. We discourage to measure colostral IgG quality by measuring only the first streaks, for it may not represent the quality of the complete milking of colostrum.

Regarding storage and treatments of colostrum after milking but before feeding it to the newborn, study designs in our results include mostly animal studies $(n=24)$ and laboratory studies $(n=26)$. Laboratory studies have high internal validity, and combined with evidence from animal studies and some population studies, we think the associations described here are quite strong. The most studied treatment of colostrum is the use of pasteurization. Effects of both duration and temperature have been studied extensively, of which the latter seems to affect colostral proteins the most. From the cited studies, sixteen studies looked into the effects of pasteurizing at $60^{\circ} \mathrm{C}$ on IgG levels, of which twelve concluded pasteurization can safely occur at $60^{\circ} \mathrm{C}$ without drastically affecting colostral IgG. Two out of 
four studies finding reduced colostral IgG concentrations looked into effects on calf serum IgG as well and concluded that calf serum IgG remained unaffected or even increased. Increasing temperature of pasteurization $\left(>60^{\circ} \mathrm{C}\right)$ and prolonged duration of pasteurization lead to decreased levels of colostral and serum IgG. Pasteurizing small batches is associated with a smaller loss of immunoglobulins compared to pasteurizing larger batches, since larger batches require prolonged exposure to heat as opposed to smaller batches. From these results we conclude that heating up until $60^{\circ} \mathrm{C}$ results in a minimal reduction of colostral and calf serum IgG concentrations. Together with findings that total bacterial counts and coliform counts are diminished by heat treatment $(47,52)$, pasteurization could provide protection against neonatal disease development (46, 139, 140). Feeding pasteurized colostrum and milk for a prolonged period (21 days) results in long term health effects, including reduced morbidity, increased body weight and increased milk production during the first lactation (141).

Freezing does not, or only slightly affect colostrum IgG concentration or serum IgG levels. Thawing by au bain-marie method up to $40^{\circ} \mathrm{C}$ is best, using a microwave results in unevenly heated colostrum, leaving some parts to remain frozen and other parts to be heated to a degree that proteins denature. Similar to the pasteurization process, we advise to thaw (and thereby freeze) in small portions to reduce the duration of heat exposure. Repeated freeze/thawing is discouraged, as colostral IgG concentrations diminish after multiple freeze/thaw cycles. We did not find studies in which thawing at room temperature or in a refrigerator was studied, however it is known that total bacterial counts will increase over time when left at room temperature $(38,39)$. Effects of freeze/thawing on other colostral immune components are not well-understood, but seems to reduce immunity cells viability. A minority of studies involved the treatment of colostrum by fermentation, freeze drying or gamma radiation. Fermentation is a method not commonly applied, however freeze drying and gamma radiation are performed by commercial suppliers of fresh colostrum replacements. In this review we aimed to address colostrum practices with regard to fresh colostrum in on-farm situations, therefore these methods of colostrum treatment were not included within this research.

For administration procedures, we found 36 animal studies and 18 population studies. The animal studies were often randomized controlled studies and thus provide strong internal validation. Together with the population studies with high external validity, we considered this a substantial body of evidence. Most studies agree that the ability to absorb IgG is highest directly after birth and declines with time. The ability to transfer macromolecules such as immunoglobulins decreases due to the process of "gut closure" (8). With respect to suckling with the dam, when calves are not assisted they often lack vigor to start suckling in time and therefore are at risk of FPI. We recommend to use an active form of colostrum feeding either by nipple bottle or esophageal feeding, to ensure a sufficient volume is ingested. Both methods are suitable for obtaining adequate transfer of passive immunity, as out of the nine studies comparing these methods, the majority (6) reports no significant differences in IgG absorption by the calf. For normal healthy calves we advise to use a bottle for colostrum feeding; esophageal tube feeding can be an invasive procedure and should only be used when calves do not voluntarily ingest a sufficient amount of colostrum. Recommendations for feeding volume vary and each of these recommendations is based on a different principle, for example providing a certain mass of IgG or providing a volume adjusted to the size and birthweight of the calf. Following the first recommendation, the volume to be fed is determined according to the quality of the colostrum: when quality of colostrum equals or exceeds $50 \mathrm{~g} / \mathrm{L}$, a calf should ingest at least 2 or 3$4 \mathrm{~L}$ according to the recommendations to ingest 100 or 150 200 grams IgG in total, respectively. When colostrum quality is low $(<50 \mathrm{~g} / \mathrm{L})$, even more should be fed divided over one or two extra feeding times. The second guideline depends on the birthweight of the calf. When the recommendation of feeding $8.5 \%$ of the $\mathrm{BW}$ is applied, $3.4 \mathrm{~L}$ is required for an average calf weighing $40 \mathrm{~kg}$ at birth. All of the guidelines described here provide an approximation of the volume to be administered. In fact, the volume that should be ingested to achieve serum IgG $>10 \mathrm{mg} / \mathrm{mL}$, depends on a combination of many factors: the quality of the colostrum (105), the bodyweight (103), and the absorption efficiency of the calf, of which the latter is affected by the timing of feeding and possibly by volume (104) and bacterial content of the colostrum (62). A finite answer to the question how much colostrum should be given exactly, remains difficult. Because some of these determinants of calf serum IgG are hardly quantifiable in on-farm situations, such as the absorption capacity and related factors, it is even more important to at least measure those parameters that can be quantified, such as colostrum quality and the weight of the newborn calf. By doing so, a farmer can adjust the colostrum volume to satisfy requirements for each individual calf. Which method should be used to determine colostrum volume, whether calculated by birthweight or colostrum quality, is probably depending on the situation on farm, e.g., which parameters can be measured and/or adjusted by the farmer. Ideally, all parameters should be taken into account for determining individual colostrum intake.

Searching systematically for milking, storing and feeding strategies of colostrum enabled us to identify current gaps regarding knowledge on colostrum management. One of the limitations in this field of research, is that the emphasis lies on how concentration of immunoglobulin $G$ in colostrum or eventually calf serum is influenced, while the effects on bioavailability and in vivo functionality are understudied. We know bacterial contamination of colostrum reduces intestinal uptake of immunoglobulins, however one of the functions of colostral immunoglobulins is to bind to pathogenic bacteria to prevent colonization. Hence, besides looking into systemic effects, local effects of colostrum immune components in the gastro-intestinal tract should be investigated as well. There is a growing body of literature that recognizes the transfer colostral leukocytes to newborns and its functionality. Liebler-Tenorio et al. found that colostral leukocytes are transferred through the epithelial barrier via follicle-associated epithelium of Peyer patches in the neonate gut (142). Protective effects of colostral leukocytes on neonatal immune development are described by 
Donovan et al. (77). In addition, Reber et al. proposed that presence of maternal leukocytes from colostrum was correlated with faster development of neonatal lymphocytes in the first week of life (143). Despite the promising effects of colostral leukocytes, very little is known about how colostrum management affects the functionality of these maternal cells in the newborn. We do know that uptake of colostral cells by the neonate is not limited by gut closure (144), however how storage methods or pasteurization affects viability or functionality of these maternal leukocytes remains uncertain. There are some limitations to our scoping review. Because of the magnitude of the available literature on colostrum management, it was impossible to cover all aspects related to colostrum management procedures and we had to delineate our scope. Therefore, we decided not to include, for example, the effects of treatment and storing on colostral microbiome or specific antibodies studied in vitro. Furthermore, in many systematic reviews, two independent persons carry out the search and selection process, we only utilized a single person. As we did not aim to quantify the combined search results in a meta-analysis procedure, we feel one person was sufficient for this scoping review.

This review was set out to evaluate current knowledge on-farm colostrum management processes and how these affect immune properties of colostrum. The findings of this study suggest that optimal colostral IgG can be achieved by milking colostrum directly after calving. If possible, we advise pasteurizing fresh colostrum for $30 \mathrm{~min}$ at $60^{\circ} \mathrm{C}$. Colostrum can safely be stored by freezing and thawing by au bain-marie is recommended to minimize IgG loss. In on-farm situations, determining the volume that should be fed is difficult. The variables contributing to absorption of IgG by the newborn calf are many and include the quality of the colostrum, the bacterial contamination,

\section{REFERENCES}

1. Godden SM, Lombard JE, Woolums AR. Colostrum management for dairy calves. Vet Clin N Am. (2019) 35:535-56. doi: 10.1016/j.cvfa.2019.07.005

2. Day MJ, Schultz RD. Veterinary Immunology: Principles and Practice. Boca Raton, FL: CRC Press (2014).

3. Butler JE. Bovine immunoglobulins: a review. J Dairy Sci. (1969) 52:1895909. doi: 10.3168/jds.S0022-0302(69)86871-2

4. Butler JE. Bovine immunoglobulins: an augmented review. Vet Immunol Immunopathol. (1983) 4:43-152. doi: 10.1016/0165-2427(83)9 0056-9

5. Gulliksen SM, Lie KI, Sølverød L, Østerås O. Risk factors associated with colostrum quality in Norwegian dairy cows. J Dairy Sci. (2008) 91:70412. doi: 10.3168/jds.2007-0450

6. Kessler EC, Bruckmaier RM, Gross JJ. Colostrum composition and immunoglobulin G content in dairy and dual-purpose cattle breeds. J Anim Sci. (2020) 98:8. doi: 10.1093/jas/skaa237

7. Meganck V, Laureyns J, Opsomer G. The importance of proper colostrum management in modern cattle. Vlaams Diergenskund Tijds. (2012) 81:37381. doi: $10.21825 /$ vdt.v81i6.18321

8. Weaver DM, Tyler JW, VanMetre DC, Hostetler DE, Barrington GM. Passive transfer of colostral immunoglobulins in calves. J Vet Int Med. (2000) 14:569-77. doi: 10.1111/j.1939-1676.2000.tb02278.x

9. Lombard J, Urie N, Garry F, Godden S, Quigley J, Earleywine T, et al. Consensus recommendations on calf- and herd-level passive immunity the time interval between birth and first moment of feeding and the weight of the calf. Despite all knowledge regarding optimal colostrum management strategies, it remains difficult to predict effects of certain colostrum management choices in practice. We therefore recommend measuring the colostral quality and/or weighing the newborn calf and adjust the volume of feeding accordingly to ensure optimal colostrum intake for each individual calf. The main emphasis in this field of study is still on the concentrations of IgG, however consequences of colostrum management on colostral leukocytes and other colostral immune compounds are understudied.

\section{AUTHOR CONTRIBUTIONS}

LR designed and performed the systematic literature search and wrote the first manuscript. All authors contributed to the article and approved the submitted version.

\section{FUNDING}

This study was financed by ZuivelNL (organisation of the Dutch dairy supply chain, The Hague, Netherlands) and the Dutch Ministry of Agriculture, Nature and Food Quality (LNV, The Hague, Netherlands) as part of 1 Health4Food (a public-private research program in the field of animal and public health, The Hague, Netherlands).

\section{SUPPLEMENTARY MATERIAL}

The Supplementary Material for this article can be found online at: https://www.frontiersin.org/articles/10.3389/fvets. 2021.668639/full\#supplementary-material in dairy calves in the United States. J Dairy Sci. (2020) 103:761124. doi: 10.3168/jds.2019-17955

10. Palczynski LJ, Bleach ECL, Brennan ML, Robinson PA. Giving calves 'the best start': Perceptions of colostrum management on dairy farms in England. Anim Welfare. (2020) 29:45-58. doi: 10.7120/09627286.29.1.045

11. Kruse V. Yield of colostrum and immunoglobulin in cattle at the first milking after parturition. Animal Prod. (1970) 12:619-26. doi: 10.1017/S0003356100029263

12. Moore M, Tyler JW, Chigerwe M, Dawes ME, Middleton JR. Effect of delayed colostrum collection on colostral IgG concentration in dairy cows. J Am Vet Med Assoc. (2005) 226:1375-7. doi: 10.2460/javma.2005.226.1375

13. Conneely M, Berry DP, Sayers R, Murphy JP, Lorenz I, Doherty ML, et al. Factors associated with the concentration of immunoglobulin G in the colostrum of dairy cows. Animal. (2013) 7:1824-32. doi: 10.1017/S1751731113001444

14. Morin DE, Nelson SV, Reid ED, Nagy DW, Dahl GE, Constable PD. Effect of colostral volume, interval between calving and first milking, and photoperiod on colostral IgG concentrations in dairy cows. J Am Vet Med Assoc. (2010) 237:420-8. doi: 10.2460/javma.237.4.420

15. Denholm KS, McDougall S, Chambers G, Clough W. Factors associated with colostrum quality in individual cows from dairy herds in the Waikato region of New Zealand. N Z Vet J. (2018) 66:115-20. doi: 10.1080/00480169.2017.1418684

16. Reschke C, Schelling E, Michel A, Remy-Wohlfender F, Meylan M. Factors associated with colostrum quality and effects on serum gamma globulin 
concentrations of calves in Swiss dairy herds. J Vet Int Med. (2017) 31:156371. doi: 10.1111 /jvim. 14806

17. Phipps AJ, Beggs DS, Murray AJ, Mansell PD, Pyman MF. Factors associated with colostrum immunoglobulin G concentration in northern-Victorian dairy cows. Aust Vet J. (2017) 95:237-43. doi: 10.1111/avj.12601

18. Silva-del-Rio N, Rolle D, Garcia-Munoz A, Rodriguez-Jimenez S, Valldecabres A, Lago A, et al. Colostrum immunoglobulin G concentration of multiparous Jersey cows at first and second milking is associated with parity, colostrum yield, and time of first milking, and can be estimated with Brix refractometry. J Dairy Sci. (2017) 100:5774-81. doi: 10.3168/jds.2016-12394

19. Lomba F, Fumiere I, Tshibangu M, Chauvaux G, Bienfet V. Immunoglobulin transfer to calves and health problems in large bovine units. Ann Recherches Vet. (1978) 9:353-60.

20. Gulinski P, Gago V. The influence of selected factors on the yield and quality of colostrum produced by Polish Holstein-Friesian cows. Acta Sci Polonorum Zootechnica. (2019) 18:11-8. doi: 10.21005/asp.2019.18.1.02

21. Samarütel J, Baumrucker CR, Gross JJ, Dechow CD, Bruckmaier RM. Quarter variation and correlations of colostrum albumin, immunoglobulin G1 and G2 in dairy cows. J Dairy Res. (2016) 83:209-18. doi: 10.1017/S0022029916000091

22. Cabral RG, Chapman CE, Aragona KM, Clark E, Lunak M, Erickson PS. Predicting colostrum quality from performance in the previous lactation and environmental changes. J Dairy Sci. (2016) 99:404855. doi: $10.3168 /$ jds.2015-9868

23. Gross JJ, Kessler EC, Bruckmaier RM. Quarter vs. composite colostrum composition assessed by Brix refractometry, specific gravity and visual color appearance in primiparous and multiparous dairy cows. Transl Anim Sci. (2017) 1:26-35. doi: 10.2527/tas2016.0001

24. Kessler EC, Pistol GC, Bruckmaier RM, Gross JJ. Pattern of milk yield and immunoglobulin concentration and factors associated with colostrum quality at the quarter level in dairy cows after parturition. J Dairy Sci. (2020) 103:965-71. doi: 10.3168/jds.2019-17283

25. Kehoe SI, Heinrichs AJ, Moody ML, Jones CM, Long MR. Comparison of immunoglobulin $G$ concentrations in primiparous and multiparous bovine colostrum. Prof Anim Sci. (2011) 27:176-80. doi: 10.15232/S1080-7446(15)30471-X

26. Pritchett LC, Gay CC, Besser TE, Hancock DD. Management and production factors influencing immunoglobulin $G_{1}$ concentration in colostrum from Holstein cows. J Dairy Sci. (1991) 74:233641. doi: 10.3168/jds.S0022-0302(91)78406-3

27. Zarei S, Ghorbani GR, Khorvash M, Martin O, Mahdavi AH, Riasi A. The impact of season, parity, and volume of colostrum on Holstein dairy cows colostrum composition. Agric Sci. (2017) 8:572-81. doi: 10.4236/as.2017.87043

28. Baumrucker CR, Burkett AM, Magliaro-Macrina AL, Dechow CD. Colostrogenesis: mass transfer of immunoglobulin $\mathrm{G}_{1}$ into colostrum. $J$ Dairy Sci. (2010) 93:3031-8. doi: 10.3168/jds.2009-2963

29. Stott GH, Fleenor WA, Kleese WC. Colostral immunoglobulin concentration in two fractions of first milking postpartum and five additional milkings. J Dairy Sci. (1981) 64:459-65. doi: 10.3168/jds.S0022-0302(81) 82594-5

30. Hostetler D, Douglas VL, Tyler J, Holle J, Steevens B. Immunoglobulin G concentrations in temporal fractions of first milking colostrum in dairy cows. Int J Appl Res Vet Med. (2003) 1:168-71.

31. Ontsouka CE, Bruckmaier RM, Blum JW. Fractionized milk composition during removal of colostrum and mature milk. J Dairy Sci. (2003) 86:200511. doi: $10.3168 /$ jds.S0022-0302(03)73789-8

32. Vetter A, Arguello A, Baumrucker C, Bruckmaier RM. Fractional milking distribution of immunoglobulin $\mathrm{G}$ and other constituents in colostrum. $J$ Dairy Sci. (2013) 96:5919-22. doi: 10.3168/jds.2013-6745

33. Godden SM, Hazel A. Relationship between milking fraction and immunoglobulin $G$ concentration in first milking colostrum from Holstein cows. Bovine Practitioner. (2011) 45:64-9. doi: 10.21423/bovine-vol45nolp64-69

34. Sroka K, Krowarsch D, Szulc T. The effect of incomplete colostrum milking on its content and on tripsin inhibitor level. Electron J Pol Agric Univ. (1998) 1:1-5.
35. Madsen BD, Rasmussen MD, Nielsen MO, Wiking L, Larsen LB. Physical properties of mammary secretions in relation to chemical changes during transition from colostrum to milk. J Dairy Res. (2004) 71:26372. doi: $10.1017 / S 0022029904000263$

36. Gomes V, Madureira KM, Soriano S, Libera AMMPd, Blagitz MG, Benesi FJ. Factors affecting immunoglobulin concentration in colostrum of healthy Holstein cows immediately after delivery. Pesquisa Vet Bras. (2011) 31(Suppl. 1):53-6. doi: 10.1590/S0100-736X2011001300009

37. Baumrucker CR, Stark A, Wellnitz O, Dechow C, Bruckmaier RM. Immunoglobulin variation in quarter-milked colostrum. J Dairy Sci. (2014) 97:3700-6. doi: 10.3168/jds.2013-7107

38. Cummins C, Lorenz I, Kennedy E. The effect of storage conditions over time on bovine colostral immunoglobulin G concentration, bacteria, and $\mathrm{pH}$. $J$ Dairy Sci. (2016) 99:4857-63. doi: 10.3168/jds.2015-10276

39. Cummins C, Berry DP, Murphy JP, Lorenz I, Kennedy E. The effect of colostrum storage conditions on dairy heifer calf serum immunoglobulin $\mathrm{G}$ concentration and preweaning health and growth rate. J Dairy Sci. (2017) 100:525-35. doi: 10.3168/jds.2016-10892

40. Langel SN, Wark WA, Garst SN, James RE, McGilliard ML, PeterssonWolfe CS, et al. Effect of feeding whole compared with cell-free colostrum on calf immune status: the neonatal period. J Dairy Sci. (2015) 98:372940. doi: $10.3168 /$ jds.2014-8422

41. McMartin S, Godden S, Metzger L, Feirtag J, Bey R, Stabel J, et al. Heat treatment of bovine colostrum. I: effects of temperature on viscosity and immunoglobulin G level. J Dairy Sci. (2006) 89:21108. doi: 10.3168/jds.S0022-0302(06)72281-0

42. Johnson JL, Godden SM, Molitor T, Ames T, Hagman D. Effects of feeding heat-treated colostrum on passive transfer of immune and nutritional parameters in neonatal dairy calves. J Dairy Sci. (2007) 90:518998. doi: 10.3168/jds.2007-0219

43. Elizondo-Salazar JA, Heinrichs AJ. Feeding heat-treated colostrum to neonatal dairy heifers: effects on growth characteristics and blood parameters. J Dairy Sci. (2009) 92:3265-73. doi: 10.3168/jds.2008-1667

44. Elizondo-Salazar JA, Heinrichs AJ. Feeding heat-treated colostrum or unheated colostrum with two different bacterial concentrations to neonatal dairy calves. J Dairy Sci. (2009) 92:4565-71. doi: 10.3168/jds.2009-2188

45. Godden SM, Hausler K, Koewler N, Brakefield K, Amburgh Mv, Rapnicki P. Effect of heat-treatment on nutritional and immune factors in bovine colostrum. In: Proceedings of the 45th Annual Conference of the American Association of Bovine Practitioners. Montreal, QC (2012). p. 229.

46. Godden SM, Smolenski DJ, Donahue M, Oakes JM, Bey R, Wells S, et al. Heat-treated colostrum and reduced morbidity in preweaned dairy calves: results of a randomized trial and examination of mechanisms of effectiveness. J Dairy Sci. (2012) 95:4029-40. doi: 10.3168/jds.2011-5275

47. Donahue M, Godden SM, Bey R, Wells S, Oakes JM, Sreevatsan S, et al. Heat treatment of colostrum on commercial dairy farms decreases colostrum microbial counts while maintaining colostrum immunoglobulin G concentrations. J Dairy Sci. (2012) 95:2697-702. doi: 10.3168/jds.2011-5220

48. Gelsinger SL, Gray SM, Jones CM, Heinrichs AJ. Heat treatment of colostrum increases immunoglobulin $G$ absorption efficiency in high, medium-, and low-quality colostrum. J Dairy Sci. (2014) 97:235560. doi: 10.3168/jds.2013-7374

49. Kryzer AA, Godden SM, Schell R. Heat-treated (in single aliquot or batch) colostrum outperforms non-heat-treated colostrum in terms of quality and transfer of immunoglobulin G in neonatal Jersey calves. J Dairy Sci. (2015) 98:1870-7. doi: 10.3168/jds.2014-8387

50. Elsohaby I, McClure JT, Dow N, Keefe GP. Effect of heat-treatment on accuracy of infrared spectroscopy and digital and optical brix refractometers for measuring immunoglobulin G concentration in bovine colostrum. $J$ Vet Int Med. (2018) 32:491-6. doi: 10.1111/jvim.15025

51. Rafiei M, Ghoorchi T, Toghdory A, Moazeni M, Khalili M. Effect of feeding heat-treated and unheated colostrum on immunoglobulin G absorption, health and performance of neonatal Holstein dairy calves. Acta Sci Anim Sci. (2019) 41. doi: 10.4025/actascianimsci.v41i1.45533

52. Mann S, Curone G, Chandler TL, Moroni P, Cha J, Bhawal R, et al. Heat treatment of bovine colostrum: I. effects on bacterial and somatic cell counts, immunoglobulin, insulin, and IGF-I concentrations, as well as the colostrum proteome. J Dairy Sci. (2020) 103:9368-83. doi: 10.3168/jds.2020-18618 
53. Mann S, Curone G, Chandler TL, Sipka A, Cha J, Bhawal R, et al. Heat treatment of bovine colostrum: II. Effects on calf serum immunoglobulin, insulin, and IGF-I concentrations, and the serum proteome. J Dairy Sci. (2020) 103:9384-406. doi: 10.3168/jds.2020-18619

54. Elizondo-Salazar JA, Jayarao BM, Heinrichs AJ. Effect of heat treatment of bovine colostrum on bacterial counts, viscosity, and immunoglobulin G concentration. J Dairy Sci. (2010) 93:961-7. doi: 10.3168/jds.2009-2388

55. Gelsinger SL, Heinrichs AJ. Comparison of immune responses in calves fed heat-treated or unheated colostrum. J Dairy Sci. (2017) 100:4090101. doi: 10.3168/jds.2016-12010

56. Sotudeh S, Khorasgani MR, Etemadifar Z, Zarkesh-Esfahani SH. Effects of spray-drying, freeze-drying and pasteurization on microbiological quality and IgG level of bovine colostrum. J Food Qual Hazards Control. (2018) 5:54-60. doi: 10.29252/jfqhc.5.2.5

57. Saldana DJ, Gelsinger SL, Jones CM, Heinrichs AJ. Effect of different heating times of high-, medium-, and low-quality colostrum on immunoglobulin G absorption in dairy calves. J Dairy Sci. (2019) 102:2068-74. doi: 10.3168/jds.2018-15542

58. Meylan M, Rings DM, Shulaw WP, Kowalski JJ, Bech-Nielsen S, Hoffsis GF. Survival of Mycobacterium paratuberculosis and preservation of immunoglobulin $\mathrm{G}$ in bovine colostrum under experimental conditions simulating pasteurization. Am J Vet Res. (1996) 57:1580-5.

59. Godden SM, Smith S, Feirtag JM, Green LR, Wells SJ, Fetrow JP. Effect of on-farm commercial batch pasteurization of colostrum on colostrum and serum immunoglobulin concentrations in dairy calves. J Dairy Sci. (2003) 86:1503-12. doi: 10.3168/jds.S0022-0302(03)73736-9

60. El-Zahar KM, El-Loly MM, Abdel-Ghany AZ. Gross antibodies, chemical composition of bovine milk and its influence by thermal stability. J Food Process Technol. (2014) 5:392. doi: 10.4172/2157-7110.1000392

61. Balthazar E, Doligez E, Leray O, Cozler Yl. A comparison of thawing methods on IgG1 concentration in colostrum of dairy cows. Rev Med Vet. (2015) 166:341-4.

62. Gelsinger SL, Jones CM, Heinrichs AJ. Effect of colostrum heat treatment and bacterial population on immunoglobulin $\mathrm{G}$ absorption and health of neonatal calves. J Dairy Sci. (2015) 98:4640-5. doi: 10.3168/jds.2014-8790

63. Shivley CB, Lombard JE, Urie NJ, Haines DM, Sargent R, Kopral CA, et al. Preweaned heifer management on US dairy operations: Part II. Factors associated with colostrum quality and passive transfer status of dairy heifer calves. J Dairy Sci. (2018) 101:9185-98. doi: 10.3168/jds.2017-14008

64. Tyler JW, Lakritz J, Hostetler DE, Douglas V, Weaver DM, Steevens $\mathrm{BJ}$, et al. Effect of pasteurization at 76 and 63 degrees $\mathrm{C}$ on the absorption of colostral IgG in calves. J Dairy Res. (2000) 67:61923. doi: 10.1017/S0022029900004441

65. Bush LJ, Contreras R, Staley TE, Adams GD. The effect of pasteurization of colostrum on absorption of immune globulins by calves. Miscellaneous Publ Oklahoma Agric Exp Station. (1982) 112:246-9.

66. Lakritz J, Tyler JW, Hostetler DE, Marsh AE, Weaver DM, Holle JM, et al. Effects of pasteurization of colostrum on subsequent serum lactoferrin concentration and neutrophil superoxide production in calves. Am J Vet Res. (2000) 61:1021-5. doi: 10.2460/ajvr.2000.61.1021

67. Stabel JR. Pasteurization of colostrum reduces the incidence of paratuberculosis in neonatal dairy calves. J Dairy Sci. (2008) 91:3600-6. doi: 10.3168/jds.2008-1107

68. El-Fattah AMA, Rabo FHRA, El-Dieb SM, El-Kashef HAS. Preservation methods of buffalo and bovine colostrum as a source of bioactive components. Int Dairy J. (2014) 39:24-7. doi: 10.1016/j.idairyj.2014.04.008

69. Teixeira AGV, Bicalho MLS, Machado VS, Oikonomou G, Kacar C, Foditsch $\mathrm{C}$, et al. Heat and ultraviolet light treatment of colostrum and hospital milk: effects on colostrum and hospital milk characteristics and calf health and growth parameters. Vet J. (2013) 197:175-81. doi: 10.1016/j.tvjl.2013.03.032

70. Shimo SP, Wu X, Ding X, Xiong L, Yan P. The influence of heat treatment in liquid whey at various $\mathrm{pH}$ on Immunoglobulin $\mathrm{G}$ and Lactoferrin from yak and cows' colostrum/milk. J Food Process Technol. (2015) 6:503. doi: 10.4172/2157-7110.1000503

71. Wiking L, Pedersen RE. Effects of heating colostrum in a microwave oven on immunoglobulin G concentration. Acta Agric Scand Sect A Anim Sci. (2009) 59:66-9. doi: 10.1080/09064700802673128
72. Jones LR, Taylor AW, Hines HC. Characteristics of frozen colostrum thawed in a microwave oven. J Dairy Sci. (1987) 70:1941-5. doi: 10.3168/jds.S0022-0302(87)80235-7

73. Haines DM, Chelack BJ, Radostits O. Freeze-thawing does not adversely effect immunoglobulin levels in colostrum. Can Vet J. (1992) 33:355-6.

74. Morrill KM, Robertson KE, Spring MM, Robinson AL, Tyler HD. Validating a refractometer to evaluate immunoglobulin $G$ concentration in Jersey colostrum and the effect of multiple freeze-thaw cycles on evaluating colostrum quality. J Dairy Sci. (2015) 98:595-601. doi: 10.3168/jds.2014-8730

75. Olson DP. Comparison of two methods for thawing colostrum before supplemental feeding to newborn calves. Bovine Pract. (1989) 24:83-6.

76. Holloway NM, Tyler JW, Lakritz J, Carlson SL, Holle J. Serum immunoglobulin $\mathrm{G}$ concentrations in calves fed fresh and frozen colostrum. J Am Vet Med Assoc. (2001) 219:357-9. doi: 10.2460/javma.2001.219.357

77. Donovan DC, Reber AJ, Gabbard JD, Aceves-Avila M, Galland KL, Holbert $\mathrm{KA}$, et al. Effect of maternal cells transferred with colostrum on cellular responses to pathogen antigens in neonatal calves. Am J Vet Res. (2007) 68:778-82. doi: 10.2460/ajvr.68.7.778

78. Holloway NM, Lakritz J, Tyler JW, Carlson SL. Serum lactoferrin concentrations in calves fed fresh or frozen colostrum. Int J Appl Res Vet Med. (2003) 1:82-6. doi: 10.2460/ajvr.2002.63.476

79. Novo SMF, Costa JFdR, Baccili CC, Sobreira NM, Maia MA, Leite $\mathrm{SBP}$, et al. Specific immune response in neonate Holstein heifer calves fed fresh or frozen colostrum. Pesquisa Vet Bras. (2017) 37:138594. doi: 10.1590/s0100-736x2017001200005

80. Novo SMF, Costa JFdR, Baccili CC, Sobreira NM, Silva BT, Oliveira PLd, et al. Effect of maternal cells transferred with colostrum on the health of neonate calves. Res Vet Sci. (2017) 112:97-104. doi: 10.1016/j.rvsc.2017.01.025

81. Costa JFdR, Novo SMF, Baccili CC, Sobreira NM, Hurley DJ, Gomes V. Innate immune response in neonate Holstein heifer calves fed fresh or frozen colostrum. Res Vet Sci. (2017) 115:54-60. doi: 10.1016/j.rvsc.2017.01.008

82. Stieler A, Bernardo BS, Donovan GA. Neutrophil and monocyte function in neonatal dairy calves fed fresh or frozen colostrum. Int J Appl Res Vet Med. (2012) 10:328-34.

83. Masuda T, Rehinarudo HY, Suzuki K, Sakai T, Morichi T. The effect of high hydrostatic pressure treatment on the preservability and the immunological activity of bovine colostrum. Asian Aust J Anim Sci. (2000) 13:13238. doi: 10.5713/ajas.2000.1323

84. Indyk HE, Williams JW, Patel HA. Analysis of denaturation of bovine IgG by heat and high pressure using an optical biosensor. Int Dairy J. (2008) 18:359-66. doi: 10.1016/j.idairyj.2007.10.004

85. Foster DM, Poulsen KP, Sylvester HJ, Jacob ME, Casulli KE, Farkas BE. Effect of high-pressure processing of bovine colostrum on immunoglobulin $\mathrm{G}$ concentration, pathogens, viscosity, and transfer of passive immunity to calves. J Dairy Sci. (2016) 99:8575-88. doi: 10.3168/jds.2016-11204

86. Mbuthia EW, Klobasa F, Gachuiri CK, Abate A. Effect of treatment with formaldehyde and formic acid on immunoglobulin content of stored bovine colostrum. Anim Feed Sci Technol. (1997) 67:291-8. doi: 10.1016/S0377-8401(97)00013-8

87. Pivont $\mathrm{P}$, Gregoire R, Antoine $\mathrm{H}$. Investigation on farmer's colostrum feeding methods: habits affecting colostral status in neonatal calves. Ann Recherches Vet. (1984) 15:509-13.

88. Todd AG, Whyte PBD. The effect of delays in feeding colostrum and the relationship between immunoglobulin concentration in the serum of neonatal calves and their rates of growth. Aust Vet J. (1995) 72:415-7. doi: 10.1111/j.1751-0813.1995. tb06191.x

89. Keulen KASv, Dobbelaar P, Wensing T, Faber JAJ, Bruggeling T, Bosch AJM. Refractometer test to monitor the administration of colostrum, and factors affecting the concentration of gamma-globulins in the serum of newborn calves. Tijdschr Diergeneeskd. (1985) 110:1057-65.

90. Smith HW, O’Neil JA, Simmons EJ. The immune globulin content of the serum of calves in England. Vet Record. (1967) 80:664-6. doi: 10.1136/vr.80.23.664

91. Michanek P, Ventrop M, Westrom B. Intestinal transmission of macromolecules in newborn dairy calves of different ages at first feeding. Res Vet Sci. (1989) 46:375-9. doi: 10.1016/S0034-5288(18)31183-4 
92. Fischer AJ, Song Y, He Z, Haines DM, Guan LL, Steele MA. Effect of delaying colostrum feeding on passive transfer and intestinal bacterial colonization in neonatal male Holstein calves. J Dairy Sci. (2018) 101:3099109. doi: 10.3168/jds.2017-13397

93. Stott GH, Marx DB, Menefee BE, Nightengale GT. Colostral immunoglobulin transfer in calves II. The rate of absorption. J Dairy Sci. (1979) 62:1766-73. doi: 10.3168/jds.S0022-0302(79)83495-5

94. Stott GH, Marx DB, Menefee BE, Nightengale GT. Colostral immunoglobulin transfer in calves. III. Amount of absorption. IV. Effect of suckling. J Dairy Sci. (1979) 62:190213. doi: 10.3168/jds.S0022-0302(79)83521-3

95. Keulen KASv, Dobbelaar P, Noordhuizen JPTM, Schwering C, Wensing T. Studies on a number of features of the supply of colostrum on dairy farms and the use of the glutaraldehyde test in evaluating the supply of colostrum. Tijdschr Diergeneeskd. (1984) 109:605-11.

96. Chigerwe M, Tyler JW, Summers MK, Middleton JR, Schultz LG, Nagy DW. Evaluation of factors affecting serum IgG concentrations in bottle-fed calves. J Am Vet Med Assoc. (2009) 234:785-9. doi: 10.2460/javma.234.6.785

97. Chigerwe M, Tyler JW, Schultz LG, Middleton JR, Steevens BJ, Spain JN. Effect of colostrum administration by use of oroesophageal intubation on serum IgG concentrations in Holstein bull calves. Am J Vet Res. (2008) 69:1158-63. doi: 10.2460/ajvr.69.9.1158

98. Osaka I, Matsui Y, Terada F. Effect of the mass of immunoglobulin (Ig)G intake and age at first colostrum feeding on serum IgG concentration in Holstein calves. J Dairy Sci. (2014) 97:6608-12. doi: 10.3168/jds.2013-7571

99. Rajala P, Castren H. Serum immunoglobulin concentrations and health of dairy calves in two management systems from birth to 12 weeks of age. $J$ Dairy Sci. (1995) 78:2737-44. doi: 10.3168/jds.S0022-0302(95)76904-1

100. Zanker IA, Hammon HM, Blum JW. Delayed feeding of first colostrum: are there prolonged effects on haematological, metabolic and endocrine parameters and on growth performance in calves? J Anim Physiol Anim Nutr. (2001) 85:53-66. doi: 10.1046/j.1439-0396.2001.00296.x

101. Fallon RJ, Harte FJ, Keane MG. Methods of artificially feeding colostrum to the new-born calf. Irish J Agric Res. (1989) 28:57-63.

102. Conneely M, Berry DP, Murphy JP, Lorenz I, Doherty ML, Kennedy E. Effect of feeding colostrum at different volumes and subsequent number of transition milk feeds on the serum immunoglobulin G concentration and health status of dairy calves. J Dairy Sci. (2014) 97:69917000. doi: 10.3168/jds.2013-7494

103. Turini L, Conte G, Bonelli F, Sgorbini M, Madrigali A, Mele M. The relationship between colostrum quality, passive transfer of immunity and birth and weaning weight in neonatal calves. Livest Sci. (2020) 238:104033. doi: 10.1016/j.livsci.2020.104033

104. Godden SM, Haines DM, Konkol K, Peterson J. Improving passive transfer of immunoglobulins in calves. II: interaction between feeding method and volume of colostrum fed. J Dairy Sci. (2009) 92:175864. doi: $10.3168 /$ jds.2008-1847

105. Morin DE, McCoy GC, Hurley WL. Effects of quality, quantity, and timing of colostrum feeding and addition of a dried colostrum supplement on immunoglobulin $\mathrm{G}_{1}$ absorption in Holstein bull calves. J Dairy Sci. (1997) 80:747-53. doi: 10.3168/jds.S0022-0302(97)75994-0

106. Jaster EH. Evaluation of quality, quantity, and timing of colostrum feeding on immunoglobulin $\mathrm{G}_{1}$ absorption in Jersey calves. J Dairy Sci. (2005) 88:296-302. doi: 10.3168/jds.S0022-0302(05)72687-4

107. Kaske M, Werner A, Schuberth HJ, Rehage J, Kehler W. Colostrum management in calves: effects of drenching vs. bottle feeding. J Anim Physiol Anim Nutr. (2005) 89:151-7. doi: 10.1111/j.1439-0396.2005.00535.x

108. Hopkins BA, Quigley JD, III. Effects of method of colostrum feeding and colostrum supplementation on concentrations of immunoglobulin $\mathrm{G}$ in the serum of neonatal calves. J Dairy Sci. (1997) 80:97983. doi: 10.3168/jds.S0022-0302(97)76023-5

109. Halleran J, Sylvester HJ, Foster DM. Short communication: apparent efficiency of colostral immunoglobulin G absorption in Holstein heifers. $J$ Dairy Sci. (2017) 100:3282-6. doi: 10.3168/jds.2016-11904

110. Renaud DL, Waalderbos KM, Beavers L, Duffield TF, Leslie KE, Windeyer MC. Risk factors associated with failed transfer of passive immunity in male and female dairy calves: a 2008 retrospective cross-sectional study. J Dairy Sci. (2020) 103:3521-8. doi: 10.3168/jds.2019-17397
111. Selman IE, McEwan AD, Fisher EW. Studies on dairy calves allowed to suckle their dams at fixed times post partum. Res Vet Sci. (1971) 12:16. doi: 10.1016/S0034-5288(18)34230-9

112. Stott GH, Marx DB, Menefee BE, Nightengale GT. Colostral immunoglobulin transfer in calves. IV. Effect of suckling. J Dairy Sci. (1979) 62:1908-13. doi: 10.3168/jds.S0022-0302(79)83522-5

113. Nocek JE, Braund DG, Warner RG. Influence of neonatal colostrum administration, immunoglobulin, and continued feeding of colostrum on calf gain, health, and serum protein. J Dairy Sci. (1984) 67:31933. doi: 10.3168/jds.S0022-0302(84)81305-3

114. Quigley JD, III, Martin KR, Bemis DA, Potgieter LND, Reinemeyer CR, et al. Effects of housing and colostrum feeding on serum immunoglobulins, growth, and fecal scores of Jersey calves. J Dairy Sci. (1995) 78:893901. doi: 10.3168/jds.S0022-0302(95)76703-0

115. Duzer M, Acar A. The effects of suckling and artificially providing colostrum (varying amount) on the passive immunity of newborn calves. Kocatepe Vet J. (2020) 13:92-7. doi: 10.30607/kvj.682585

116. Edwards SA, Broom DM. The period between birth and first suckling in dairy calves. Res Vet Sci. (1979) 26:255-6. doi: 10.1016/S0034-5288(18)32930-8

117. Brignole TJ, Stott GH. Effect of suckling followed by bottle feeding colostrum on immunoglobulin absorption and calf survival. J Dairy Sci. (1980) 63:4516. doi: 10.3168/jds.S0022-0302(80)82952-3

118. Logan EF, Muskett BD, Herron RJ. Colostrum feeding of dairy calves. Vet Record. (1981) 108:283-4. doi: 10.1136/vr.108.13.283

119. Bragg R, Macrae A, Lycett S, Burrough E, Russell G, Corbishley A. Prevalence and risk factors associated with failure of transfer of passive immunity in spring born beef suckler calves in Great Britain. Prev Vet Med. (2020) 181:105059. doi: 10.1016/j.prevetmed.2020.105059

120. Johnsen JF, Viljugrein H, Boe KE, Gulliksen SM, Beaver A, Grondah $\mathrm{AM}$, et al. A cross-sectional study of suckling calves' passive immunity and associations with management routines to ensure colostrum intake on organic dairy farms. Acta Vet Scand. (2019) 61:7. doi: 10.1186/s13028-019-0442-8

121. Michanek P. Transfer of Colostral Immunoglobulin to Newborn Dairy Calves. Effects of Housing on Suckling Patterns and Consequences for the Intestinal Transmission of Macromolecules. Uppsala: Report Department of Agricultural Biosystems and Technology, Swedish University of Agricultural Sciences (1994).

122. Edwards SA, Broom DM, Collis SC. Factors affecting levels of passive immunity in dairy calves. Br Vet J. (1982) 138:23340. doi: 10.1016/S0007-1935(17)31087-4

123. McBeath DG, Logan EF. Influence of neonatal management on serum immunoglobulin levels of suckled calves. Vet Record. (1974) 95:466. doi: 10.1136/vr.95.20.466-a

124. Petrie L. Maximising the absorption of colostral immunoglobulins in the newborn dairy calf. Vet Record. (1984) 114:157-63. doi: 10.1136/vr.114.7.157

125. Urday $\mathrm{K}$, Chigerwe $\mathrm{M}$, Tyler JW. Voluntary colostrum intake in Holstein heifer calves. Bovine Pract. (2008) 42:198-200. doi: 10.21423/bovine-vol42no2p198-200

126. Bilik K, Niwinska B, Lopuszanska-Rusek M, Fijal J. Optimization of rearing dairy breed calves according to organic principles. Ann Anim Sci. (2013) 13:341-55. doi: 10.2478/aoas-2013-0014

127. Franklin ST, Amaral-Phillips DM, Jackson JA, Campbell AA. Health and performance of Holstein calves that suckled or were hand-fed colostrum and were fed one of three physical forms of starter. J Dairy Sci. (2003) 86:2145-53. doi: 10.3168/jds.S0022-0302(03)73804-1

128. Devarnavadagi AS, Rajeshwari YB, Patil SS, Krishnamoorthy U, Satyanarayana K, Patil VM, et al. A study on the effect of colostrum feeding method on serum IgG concentration in neonatal crossbred calves. $J$ Exp Zool. (2015) 18:867-9.

129. Molla A. Immunoglobulin levels in calves fed colostrum by stomach tube. Vet Rec. (1978) 103:377-80. doi: 10.1136/vr.103.17.377

130. Lateur-Rowet HJM, Breukink HJ. The failure of the oesophageal groove reflex, when fluids are given with an oesophageal feeder to newborn and young calves. Vet Q. (1983) 5:68-74. doi: 10.1080/01652176.1983. 9693874

131. McGee M, Drennan MJ, Caffrey PJ. Effect of age and nutrient restriction pre partum on beef suckler cow serum immunoglobulin concentrations, 
colostrum yield, composition and immunoglobulin concentration and immune status of their progeny. Irish J Agric Food Res. (2006) 45:157-71.

132. Bradley JA, Niilo L. Immunoglobulin transfer and weight gains in suckled beef calves force-fed stored colostrum. Can J Comp Med. (1985) 49:152-5.

133. Elizondo-Salazar JA, Jones CM, Heinrichs AJ. Feeding colostrum with an esophageal feeder does not reduce immunoglobulin G absorption in neonatal dairy heifer calves. Prof Anim Sci. (2011) 27:561-4. doi: 10.15232/S1080-7446(15)30539-8

134. Chigerwe M, Coons DM, Hagey JV. Comparison of colostrum feeding by nipple bottle versus oroesophageal tubing in Holstein dairy bull calves. J Am Vet Med Assoc. (2012) 241:104-9. doi: 10.2460/javma.241.1.104

135. Bonk S, Nadalin A, Heuwieser W, Veira D. Lying behaviour and IgGlevels of newborn calves after feeding colostrum via tube and nipple bottle feeding. J Dairy Res. (2016) 83:298-304. doi: 10.1017/S00220299 16000285

136. Desjardins-Morrissette M, Niekerk JKv, Haines D, Sugino T, Oba M, Steele MA. The effect of tube versus bottle feeding colostrum on immunoglobulin G absorption, abomasal emptying, and plasma hormone concentrations in newborn calves. J Dairy Sci. (2018) 101:4168-79. doi: 10.3168/jds.2017-13904

137. Shah AM, Naeem M, Shah MG, Haaroon M, Peng Q, Wang Z. Effects of various colostrum feeding methods on growth performance and immunity of Holstein-Friesian calves. Pak J Zool. (2019) 51:21616. doi: 10.17582/journal.pjz/2019.51.6.2161.2166

138. Adams GD, Bush LJ, Horner JL, Staley TE. Two methods for administering colostrum to newborn calves. J Dairy Sci. (1985) 68:773-5. doi: 10.3168/jds.S0022-0302(85)80887-0

139. Jamaluddin AA, Hird DW, Thurmond MC, Carpenter TE. Effect of preweaning feeding of pasteurized and nonpasteurized milk on postweaning weight gain of heifer calves on a Californian dairy. Prev Vet Med. (1996) 28:91-9. doi: 10.1016/0167-5877(96)01040-9
140. Malmuthuge N, Chen Y, Liang G, Goonewardene LA, Guan L. Heattreated colostrum feeding promotes beneficial bacteria colonization in the small intestine of neonatal calves. J Dairy Sci. (2015) 98:804453. doi: $10.3168 /$ jds.2015-9607

141. Armengol R, Fraile L. Feeding calves with pasteurized colostrum and milk has a positive long-term effect on their productive performance. Animals. (2020) 10:1494. doi: 10.3390/ani10091494

142. Liebler-Tenorio EM, Riedel-Caspari G, Pohlenz JF. Uptake of colostral leukocytes in the intestinal tract of newborn calves. Vet Immunol Immunopathol. (2002) 85:33-40. doi: 10.1016/S0165-2427(01)00404-4

143. Reber AJ, Donovan DC, Gabbard J, Galland K, Aceves-Avila M, Holbert KA, et al. Transfer of maternal colostral leukocytes promotes development of the neonatal immune system Part II. Effects on neonatal lymphocytes. Vet Immunol Immunopathol. (2008) 123:30513. doi: $10.1016 /$ j.vetimm.2008.02.009

144. Schnorr KL, Pearson LD. Intestinal absorption of maternal leucocytes by newborn lambs. J Reprod Immunol. (1984) 6:329-37. doi: 10.1016/0165-0378(84)90031-7

Conflict of Interest: The authors declare that the research was conducted in the absence of any commercial or financial relationships that could be construed as a potential conflict of interest.

Copyright (c) 2021 Robbers, Jorritsma, Nielen and Koets. This is an open-access article distributed under the terms of the Creative Commons Attribution License (CC $B Y)$. The use, distribution or reproduction in other forums is permitted, provided the original author(s) and the copyright owner(s) are credited and that the original publication in this journal is cited, in accordance with accepted academic practice. No use, distribution or reproduction is permitted which does not comply with these terms. 